\title{
Research on Students' Innovation and Entrepreneurship Education Reform of Forestry Majors
}

\author{
Laicheng Yang, Yifu Yuan*, An Mao* \\ College of Forestry, Shandong Agricultural University, Taian, China \\ Email address: \\ yanglcc@126.com (L. Yang), yuanyf16@163.com (Y. Yuan), dannymaoan@126.com (A. Mao) \\ ${ }^{*}$ Corresponding author
}

To cite this article:

Laicheng Yang, Yifu Yuan, An Mao. Research on Students' Innovation and Entrepreneurship Education Reform of Forestry Majors. International Journal of Secondary Education. Vol. 8, No. 4, 2020, pp. 115-120. doi: 10.11648/j.ijsedu.20200804.12

Received: October 2, 2020; Accepted: October 13, 2020; Published: October 26, 2020

\begin{abstract}
Innovation and entrepreneurship education aims to cultivate talents with basic entrepreneurial quality and pioneering personality. It is not only aimed at cultivating students' entrepreneurial awareness, spirit and ability, but also for the whole society. It is aimed at those entrepreneurial groups who intend to start their own businesses, have started businesses and have successfully started businesses, to cultivate innovative thinking and entrepreneurship in stages and levels ability training education. According to the author's practical experience in guiding the innovation and entrepreneurship education and various competitions for forestry major students in recent years, there are still many deficiencies in the innovation and entrepreneurship education of forestry students, including both the common problems of domestic innovation and entrepreneurship education, and the unique problems of forestry discipline itself. Based on the investigation and analysis of the cultivation of innovation and entrepreneurship ability of students in forestry disciplines, combined with the characteristics of forestry disciplines, this paper explores and practices the mode that meets the needs of the cultivation of forestry students' innovation and entrepreneurship ability, promotes the reform of personnel training mode, enhances the innovative spirit, entrepreneurial awareness and innovation and entrepreneurial ability of students, and cultivates talents of forestry disciplines.
\end{abstract}

Keywords: Forestry Major, Innovation and Entrepreneurship, Education Reform

\section{Introduction}

Innovation training is an undergraduate individual or team, under the guidance of tutors, to independently complete innovative research project design, research conditions preparation and project implementation, research report writing, achievement exchange, etc. Through the implementation of the national innovation and entrepreneurship training program for college students, it is necessary to Promote Colleges and universities to change their educational ideas, reform the personnel training mode, strengthen the training of innovation and entrepreneurship ability, enhance the innovation ability of college students and the entrepreneurial ability on the basis of innovation, and cultivate high-level innovative talents to meet the needs of the construction of an innovative country [1]. Currently, China's higher education has entered mass education from elite education. Meanwhile, in order to meet the needs of diversified talents in economic society, colleges and universities are actively seeking effective ways to improve the quality and level of education, and explore a new mode of diversified and innovative talents training. The general office of the State Council issued the implementation opinions on deepening the reform of innovation and entrepreneurship education in Colleges and universities, putting forward the overall goal of "comprehensively deepening the reform of innovation and entrepreneurship education in colleges and universities". The cultivation of innovative talents is the theme of innovation and entrepreneurship education, and innovation and entrepreneurship ability is the ultimate goal of innovative talents training. As the main place of higher education, University has three functions: talent training, scientific research and social service. The most fundamental function is talent training. To build an innovative talent training system, to cultivate high-quality talents with innovation, entrepreneurship and practical ability is not only the fundamental requirement of the state to build the innovation system, but also the basic requirement for 
colleges and universities It is not only the practical needs of serving local economic and social development, but also the inevitable choice of sustainable development of the school itself [2-4].

At present, college students' innovation and entrepreneurship education is in full swing in colleges and universities, and has gained a lot of achievements and accumulated a lot of experience. Forestry is a specialty with distinctive characteristics, which is close to mountains, water and nature. With the progress of ecological civilization construction in recent years, its connotation has undergone profound changes. It has expanded from traditional planting production to landscape design, horticultural design, flowers, tea, grass industry, fine carpentry, cultivation and utilization of economic forest, protection and utilization of wild animal and plant resources, forest eco-tourism planning, etc. Areas closely related to daily life. The market prospect of these fields is broad, and the stage of innovation and entrepreneurship is very large. However, according to the practical experience of the project applicant guiding the innovation and entrepreneurship education and various competitions of forestry university students in recent years, there are still many deficiencies in the innovation and entrepreneurship education of forestry students, including both the common problems existing in domestic innovation and entrepreneurship education, and the unique problems of forestry discipline itself, which are embodied in: insufficient awareness of innovation and entrepreneurship and there are several aspects, such as insufficient development of innovative resources in forestry field, insufficient communication between disciplines, and disconnection from production practice (Table 1) [5].

Based on the investigation and Analysis on the cultivation of innovation and entrepreneurship ability of forestry college students, this project explores and practices the mode that meets the needs of Forestry University Students' innovation and entrepreneurship ability cultivation, and promotes the reform of forestry discipline talent training mode. The reform and practice of the cultivation of Forestry College Students' innovation and entrepreneurship ability, and the enhancement of innovation spirit, entrepreneurship awareness and innovation and entrepreneurship ability, have a great role in promoting the quality of talent training of forestry discipline [6].

\section{Reform Methods}

\subsection{Reform the Scientific Research Management System of Students}

Shandong Agricultural University Students' innovation and entrepreneurship training program has been implemented for several years, and has achieved remarkable results. The selected topics of the applied projects are scientific and reasonable, and pay more attention to innovation. The applicants are usually sophomores. They apply through the establishment of a reasonable team, and each project is equipped with a tutor. The project evaluation is based on the principle of "openness, fairness and justice", according to the preliminary examination of disciplines and the preliminary examination of colleges, and finally the decision of whether to set up a project is based on the evaluation opinions of the expert group. Among them, excellent projects are recommended to apply for provincial and national college students' innovation and innovation Industry training program [7-9].

Most young people are also reluctant to engage in furniture However, some problems have been found in the implementation of the project: at the beginning of the application, the enthusiasm of students is generally very high. With the progress of the project, experimental operation, material search, report submission and other procedures are required, and the implementation is difficult, and students will have a certain "sense of frustration", and their enthusiasm gradually decreases; sophomores are not fully involved in the study of professional courses, and their professional basic knowledge is relatively weak, encountered resistance in the design and implementation of the project, leading to difficulties in project initiation and slow progress; students lack of project management experience, do not understand the rules of the use of funds, resulting in project progress lag and non-standard reimbursement. In recent years, the management of funds in colleges and universities is chaotic, and financial governance problems occur frequently. Therefore, reestablishing the financial governance structure of college students can effectively complete the internal control optimization scheme of university students' scientific research funds. It is of great significance to standardize the management of scientific research funds for college students.

In view of the above problems, it is necessary to reform the scientific research management system of college students from the aspects of system construction, target orientation and content scope, improve and strengthen the construction of university students' innovation and entrepreneurship management platform, and promote the cultivation of innovation and entrepreneurship awareness. From the aspects of system construction, target orientation and content scope, this paper analyzes and draws on the innovation and Entrepreneurship Management System of other universities and related majors, and formulates the preliminary framework of university students' scientific research management system, including the management of students' scientific research projects and funds, the establishment of scientific research archives, the long-term planning of scientific research, and the incentive mechanism [10].

At present, a preliminary framework for the management system of university students' scientific research has been worked out, including the management of students' scientific research projects and funds, the establishment of scientific research archives, the long-term planning of scientific research, and the incentive mechanism. Meanwhile, the project management training has been strengthened, and the relevant management personnel are invited to introduce the 
application and implementation of the plan, budget and management, etc. for the student applicants, and the instructors are invited to introduce the items The common problems and solutions in the process of project implementation, the materials to be prepared at each node, and the expense reimbursement specifications. Through the establishment and implementation of scientific research platform and system, the innovation and entrepreneurship system of college students is standardized to ensure the good operation of innovation and entrepreneurship projects [4].

With the reform of modern education system, college students' innovation and entrepreneurship education has received universal attention. Especially in the new situation of increasing employment pressure, scientific cultivation of
College Students' innovation consciousness and entrepreneurial ability will not only help to improve the quality of college education, but also promote the overall and rapid development of social economy, In order to promote the overall innovation and entrepreneurship education of college students to a new level, this paper believes that we should speed up the construction of the ecological system of College Students' innovation and entrepreneurship education, focus on the construction of ecological development cultural environment of College Students' innovation and entrepreneurship education, Further optimize and improve the innovation and entrepreneurship education support system.

Table 1. Common problems existing in domestic innovation and entrepreneurship education, and the unique problems of forestry discipline.

\begin{tabular}{lll}
\hline No. & $\begin{array}{l}\text { Deficiencies in the innovation and entrepreneurship education of forestry } \\
\text { students }\end{array}$ & Possible reasons \\
\hline 1 & Insufficient awareness of innovation and entrepreneurship & Lack of systematic management \\
2 & Insufficient development of innovative resources in forestry field & Lack of forestry innovation ability and core competitiveness \\
3 & Insufficient communication between disciplines & Insufficient integration of forestry and other disciplines \\
4 & Disconnection from production practice & Lack of forestry practical experience \\
\hline
\end{tabular}

\subsection{Reform Innovation and Entrepreneurship Practice Training Activities}

In recent years, we have made a lot of achievements in entrepreneurship training and innovation training. This paper analyzes the causes of the problems, which are embodied in the following aspects: insufficient awareness of innovation and Entrepreneurship (lack of systematic management and training platform), insufficient development of innovative resources in forestry field (insufficient forestry innovation ability and core competitiveness), insufficient communication between disciplines (insufficient integration of forestry and other disciplines), and disconnection from production practice (lack of forestry practical experience) noodles [7].

In this regard, targeted measures should be taken to strengthen education in the development of forestry innovation resources, inter disciplinary integration, foreign exchange, and forestry production practice, fully explore the advantages of forestry, and promote the improvement of the quality level and core competitiveness of college students' innovation and entrepreneurship education. For example, we should take interdisciplinary and international cooperation training, set up interdisciplinary and production application-oriented topics for college students, and carry out forestry innovation competition, so as to realize the organic integration of curriculum learning, scientific research and practice. In terms of interdisciplinary cooperation training, we should break the boundaries between disciplines, strengthen mutual understanding between disciplines and specialties, and set up a "double tutor" system. The first instructor is the subject teacher, and the second is the interdisciplinary instructor. In terms of international cooperative training, we have carried out joint training with the School of forestry resources of Mississippi State University in the United States to expand the international vision of students In terms of subject setting, more interdisciplinary subjects or topics closely combined with production and application should be set up to enable students to acquire more comprehensive and useful professional knowledge.

\subsection{Enhance the Ability of Innovation and Entrepreneurship Competition}

The competition of innovation and entrepreneurship among undergraduate students is an important part of innovation and entrepreneurship education. Through competition, it can promote the creatively study and apply knowledge, change knowledge into innovation and entrepreneurship, and improve their comprehensive quality.

At present, college students' innovation and entrepreneurship competition is in full swing, which plays an important role in improving college students' innovation and entrepreneurship ability. Most of the teaching and training modes in colleges and universities are based on theoretical learning and supplemented by practical training. Although there are practical courses in the teaching process, they lack of challenge and effectiveness. In order to improve the students' ability of innovation and entrepreneurship competition, the college set up interdisciplinary innovation and entrepreneurship competition to simulate various competition rules. After the competition, students carefully summarize and summarize, through the competition, improve the practical ability of innovative thinking, cultivate team cooperation ability, fully mobilize learning enthusiasm, guide students to improve their comprehensive ability, so as to achieve the purpose of innovation and entrepreneurship 
competition.

\subsection{Reform the Curriculum System of Innovation and Entrepreneurship Education}

The curriculum system is the basic way to realize the innovation and entrepreneurship education and the core problem to be solved. However, at present, the curriculum system of innovation and entrepreneurship education in most colleges and universities is not perfect, and there are many problems, such as failing to highlight the cultivation of practical ability of innovation and entrepreneurship, failing to combine closely with professional courses, and failing to incorporate innovation and entrepreneurship education into talent training objectives and training In the scheme, it is seriously divorced from education and teaching, scientific research and production practice.

We should reform the curriculum system of innovation and entrepreneurship education, optimize and adjust the innovation and entrepreneurship curriculum in the existing talent training program, increase the content of practical training, study the undergraduate teaching syllabus, curriculum, teaching plan, credit system, training program and other contents of forestry related majors, and build a more scientific and reasonable innovation and entrepreneurship education curriculum system and credit setting And to adjust the undergraduate teaching program, curriculum, teaching plan, credit system and training program of forestry related majors. For example: (1) increase the proportion of experimental class hours and increase the content of practice, so that students can understand more comprehensive professional knowledge, and lay a more solid foundation for future related production, scientific research and management; (3) increase the content of case teaching, pay attention to improve the timeliness of cases in the teaching process, enhance the interactivity in case teaching, add teaching practice links, and attach importance to learning Students' feedback; (3) increase the content of Ideological and political course, construct the whole staff, the whole course and the whole course of education pattern, make all kinds of courses and ideological and political theory courses go together, form a synergistic effect, and establish students' correct three views. The above series of curriculum reform measures have achieved good teaching effect, not only improve the teaching quality, but also enhance the students' innovation and entrepreneurship ability.

\section{Constructing the Curriculum System of Innovation and Entrepreneurship Education}

\subsection{Establish a Platform for Innovation and Entrepreneurship Education}

The theoretical education of the universal education platform is oriented to all students. Through the opening of general courses, students are educated in the basic knowledge of innovation and entrepreneurship culture, focusing on the cultivation of students' innovation and entrepreneurship spirit and culture, guiding students to master the basic knowledge of innovation and entrepreneurship, and to stimulate the initial awareness of innovation and entrepreneurship, so as to understand the impact of innovation and entrepreneurship on the country, schools and individuals The significance of the exhibition is to enhance the sense of responsibility and responsibility of the youth in the new era. For example, while taking courses such as employment guidance and career planning, the school can require all freshmen to conduct career assessment and find out the development direction according to their own characteristics and personalities.

\subsection{Establish a Professional Education Platform for Innovation and Entrepreneurship}

The theoretical education in the professional education platform should adhere to the principle that innovation and entrepreneurship work runs through the whole process of talent training. For all students of different disciplines and majors, combined with the characteristics of the specialty and the content of teaching materials, the basic knowledge of innovation and entrepreneurship should be integrated into the professional courses, leading students to understand the frontier new theory, new technology and new technology, and pay attention to the cultivation of students' innovative and entrepreneurial personality let more teachers and students understand technology and art, love innovation and creation. The practical education in the professional education platform mainly through entrepreneurship research, enterprise visits and other activities to guide students to go deep into the enterprise, understand the actual needs of professional related industries and posts for talents, carry out face-to-face communication with successful entrepreneurs, at the same time, preliminarily integrate the professional theoretical education knowledge with the actual production, and realize the preliminary transformation and training of book theoretical knowledge Cultivate students' ability and skills of innovation and entrepreneurship.

\subsection{Establish Innovation and Entrepreneurship Guidance Platform}

For the students with innovation consciousness and entrepreneurial potential, the innovation and entrepreneurship counseling platform breaks the barriers between departments and colleges and conducts interdisciplinary professional elective courses, which can provide innovative and entrepreneurial courses. Innovative elective courses can carry out subject frontier topics, professional research progress, etc., and entrepreneurial elective courses can carry out entrepreneurship management. It focuses on guiding students to understand the basic process and foundation of entrepreneurship. For students with innovation awareness and entrepreneurial potential, the practical education of 
innovation and entrepreneurship counseling platform can carry out "Challenge Cup" entrepreneurship plan competition college students' electronic design competition, invention creation and patent application, and guide students to use the methods and skills they have learned to analyze and solve problems in reality, and improve students' innovation through seamless connection of theory and practice Entrepreneurial ability.

\subsection{Establish Micro Entrepreneurship Cultivation Platform}

For the students who are starting a business or are successful in starting a business, the theoretical education of micro entrepreneurship cultivation platform can introduce the knowledge of operation management, marketing, strategic planning, enterprise venture capital and financial management to the students by setting up a series of related courses, so as to help students master the methods and skills of successful entrepreneurship or enterprise operation.

It is necessary to improve the innovation and entrepreneurship ability of college students, form a good atmosphere of innovation and entrepreneurship education, build a perfect innovation and entrepreneurship cultivation system, form a virtuous cycle system like the ecological system, and build a comprehensive three-dimensional innovation and entrepreneurship education ecological cultivation system. This system includes universities, government, enterprises, families, students and other subsystems. The subsystems are interconnected, interact and support each other, forming a complete innovation and entrepreneurship education and cultivation system.

\section{Summary}

As mentioned above, the reform methods mentioned in this article include: reform the scientific research management system of students, reform innovation and entrepreneurship practice training activities, enhance the ability of innovation and entrepreneurship competition, and reform the curriculum system of innovation and entrepreneurship education. At the beginning of the reform, the undergraduate students majoring in forestry in Shandong Agricultural University will benefit. At the same time, the research group will comprehensively sort out and summarize the teaching reform experience, write and publish teaching reform papers, so that the achievements will be gradually extended to the reform and practice of undergraduate training mode of forestry related disciplines in agricultural and forestry universities in China, which can benefit thousands of students every year. In a word, carrying out the reform and practice of the cultivation of forestry related college students' innovation and entrepreneurship ability, and strengthening the innovation spirit, entrepreneurship awareness and innovation and entrepreneurship ability, will have a great role in promoting the quality of forest related talents training.

\section{Author Contributions}

The Manuscript was written through contributions of all authors. All authors have given approval to the final version of the manuscript.

\section{Conflicts of Interest}

The authors declare that they have no competing interests.

\section{Acknowledgements}

The research was supported by funding from Shandong Agricultural University teaching reform project "Reform and practice of innovation and entrepreneurship cultivation of forestry related college students under the background of mass entrepreneurship and innovation" and Shandong Agricultural University graduate education and teaching reform key project (No: JYZD2018014).

\section{References}

[1] Mao A, Yu X. Y, Lu F. D, Yuan Y. F, Li Q (2019) Research on the Reform of Personnel Training Mode for Forest Related Majors by Foreign Exchange Programs. Education Teaching Forum, 43: 103-105.

[2] Li Q, Yang L. C, Yu X. Y, Lu F. D, Sang Y. L, Yuan Y. F, Mao A (2019) Study on the Bilingual Teaching Reform of Adhesive and Coating Course under the Background of Cooperation Program. Education Teaching Forum, 50: 124-125.

[3] Zhang S. X, Wang Y. W, Liu X. L, Wang H. L (2011) Cultivating Entrepreneurial Talents of Sericulture under the Guidance of Specialty Expansion. China Agricultural Education, 5: 82-85.

[4] Gao P, Zhang G. C, Liu X (2007) Practice and Research for Improving the Teaching System of the Traditional Discipline of Soil and Water Conservation. Higher Agricultural Education, 8: 61-63.

[5] Liu C. H, Li X. H, Li G, Yue Q. R, Ren Y. G (2014) Practice and Exploration of the Undergraduate Innovation and Entrepreneurship Training Program. Research and Exploration in Laboratory, 33 (5): 163-166.

[6] Sun W. Q, Meng C. Y, Wang W. J (2020) A Study on the Curriculum System for the Cultivation of Innovation and Entrepreneurship Ability in Application-oriented Universities. Modern Education Management, 7: 75-81.

[7] Zhang Y, Wang S. M, Wang X (2020) Research on the Path of Cultivating College Students Innovation and Entrepreneurship. Value Engineering, 39 (10): 278-279.

[8] Xu X. H, Huang D. Q, Xiao H. X (2020) On the Employment Satisfaction of College Students from the Perspective of "Mass Entrepreneurship and Innovation" Education. Education and Vocation, 17: 67-72.

[9] Yao Y. Q (2020) Innovation and Promotion of College Students' Entrepreneurship in China. Journal of China Institute of Industrial Relations, 34 (2): 19-26. 
[10] Ma J. D, Wang F, (2020) A Comparative Study on the Undergraduates' Innovation \& Entrepreneurship Education in Britain and in China. Journal of Lanzhou Jiaotong University, 39 (2): $147-151$. 